\title{
60 years of dioxygen activation
}

\author{
Lawrence Que $^{1}$
}

Published online: 11 February 2017

(C) SBIC 2017

In 1955, Osamu Hayaishi [1] and Howard S. Mason [2] independently published papers in the Journal of the American Chemical Society reporting evidence for the incorporation of $\mathrm{O}$ atoms from dioxygen into oxidation products of two enzyme-catalyzed reactions [3, 4]. Mason and coworkers found that a dicopper enzyme then referred to as phenolase (and now called tyrosinase) converted monophenols to diphenols (i.e., catechols), while Hayaishi and coworkers reported that a nonheme monoiron enzyme then referred to as pyrocatechase (and now called catechol 1,2-dioxygenase) catalyzed the oxidative cleavage of catechol to cis,cis-muconic acid (Scheme 1). Prior to these developments, $\mathrm{O}_{2}$ was thought to act simply as an electron sink, with the oxygen atoms incorporated into organic products of biochemical transformations all derived from water. Mason's and Hayaishi's results represented the first examples of 'oxygen transferases' (now called oxygenases) in nature and gave birth to the field of dioxygen activation. In 1986, Professor Hayashi was recognized by the Wolf Foundation and awarded the 1986 Wolf Prize in Medicine "for his discovery of the oxygenase enzymes and elucidation of their structure and biological importance".

It has been over 60 years, since these two landmark papers were published. They have stimulated many scientists to investigate the phenomenon of dioxygen activation in nature, resulting in the identification of many enzymes as oxygenases, which use a variety of redox-active centers, both organic and inorganic, as agents to activate $\mathrm{O}_{2}$ for the transformations of biomolecules and the biosynthesis of

Lawrence Que

larryque@umn.edu

1 Department of Chemistry, Center for Metals in Biocatalysis, University of Minnesota, Minneapolis, MN 55455, USA natural products. Many papers and books have been published on this topic, and many conferences have been held. I had the pleasure of meeting Professor Hayaishi in 1981 when he invited me to attend the 2nd second International Symposium on Oxygenases and Oxygen Metabolism, Hakone, Japan, in November, 1981 (see Fig. 1, top right). It was my first invitation to speak at an international conference, and I was very excited to meet the scientists who laid the microbiological and biochemical groundwork for my subsequent spectroscopic and biomimetic experiments on nonheme iron enzymes. It was a stimulating experience, both scientifically and culturally. Professor Hayaishi and his colleagues were marvelous hosts, at a meeting held in the shadow of Mt. Fuji with fall foliage in its full glory. The most recent edition of this conference, held in Kyoto in 2006, celebrated the 50th anniversary of the discovery of oxygenases and coincided with the emergence of the cherry<smiles>Cc1ccc(O)cc1C</smiles><smiles>Cc1cc(O)c(O)cc1C</smiles><smiles>Oc1ccccc1O</smiles>
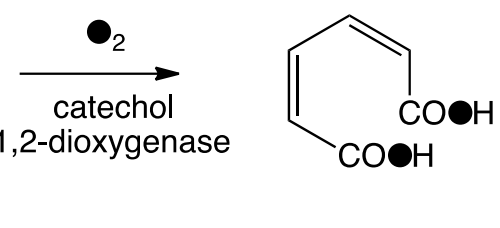

Scheme 1 Landmark reactions demonstrating the first examples of dioxygen activation found in nature 
blossoms (see Fig. 1, bottom left). A special issue of Biochemical and Biophysical Research Communications was assembled to commemorate this event (Vol. 338, Issue no. 1).

In organizing this special issue of JBIC commemorating 60 years of dioxygen activation, I have sought to assemble a set of articles on this broad topic that provide snapshots of where the field stands today. Two articles provide a more historical perspective: one by Emma Raven on heme dioxygenases [5], the first example of which was reported by Hayaishi in 1957 [6], and the other by Kiyoshi Fujisawa on the accomplishments of Nobumasa Kitajima and his students on the discovery of $\mathrm{O}_{2}$ adducts of synthetic nonheme copper and iron centers, which have strongly influenced this field [7]. In the heme enzyme section, Huang and Groves discuss the impact of the rebound mechanism Groves first postulated 40 years ago [8] on our understanding of $\mathrm{C}-\mathrm{H}$ activation and the potential for applying this notion for the development of novel biomimetic $\mathrm{C}-\mathrm{H}$ functionalization reactions [9]. This article is complemented by a new look at the role of thiolate ligation in cytochrome P450 taken by Green and co-authors [10] and an examination of more recent developments in the biosynthesis of hydrocarbons involving iron enzymes by Makris and co-authors [11].

In the next section, Karlin and co-authors cover the most recent advancements in the structures,
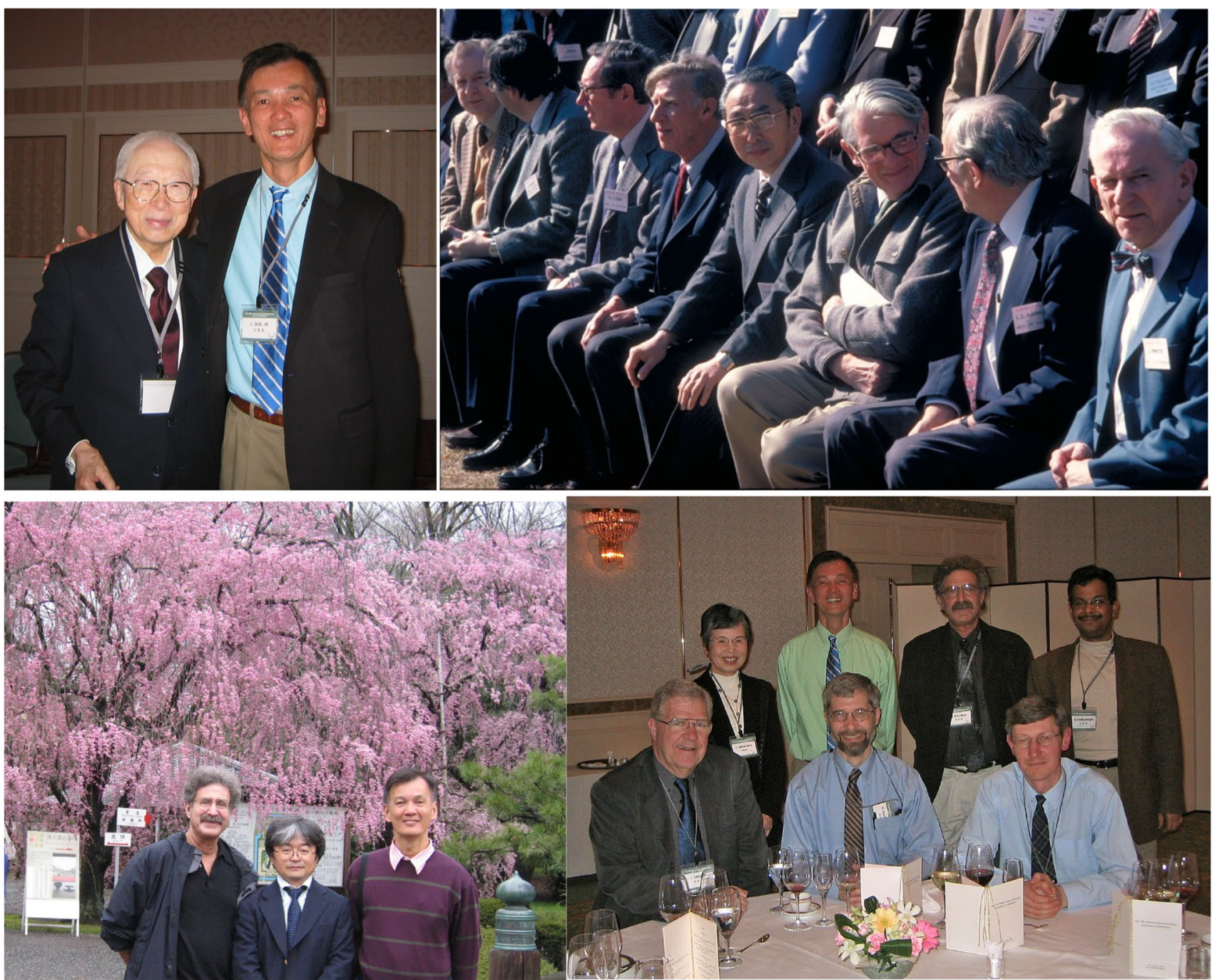

Fig. 1 Photographs taken at conferences in Japan organized by Professor Osamu Hayaishi. Top left Professor Osamu Hayaishi and Larry Que in 2006 (photo credit: L. Que). Top right setting up for the conference picture at the 2nd International Symposium on Oxygenases and Oxygen Metabolism, held in Hakone, Japan in November 1981. Left to right Bo Malmström, Jack Peisach, Minor J. Coon, Konrad Bloch, Osamu Hayaishi, Howard Mason, I. C. Gunsalus, and Lars
Ernster (photo credit: John Lipscomb). Bottom left Ed Solomon, Kiyoshi Fujisawa, and Larry Que enjoying the cherry blossoms at Nijo Castle near the 2006 Conference site (photo credit: L. Que). Bottom right Speakers of the Iron Session of the 2006 Conference. Seated: Jay Groves, Bob Hausinger, and Tim Bugg. Standing: Teruko Nakazawa, Larry Que, Ed Solomon, and S. Ramaswamy (photo credit: L. Que) 
spectroscopy, and reaction mechanisms for dioxygenactivating copper enzymes and how relevant synthetic models have contributed to our understanding of their mechanisms [12]. Stack and co-authors discuss the potential relevance of the $\mathrm{Cu}(\mathrm{III})$ oxidation state in biological redox processes, presenting numerous synthetic examples that access this oxidation state from $\mathrm{Cu}(\mathrm{I})$ ligated in enzyme-like environments and dioxygen. Despite the synthetic chemical precedence, structural or spectroscopic evidence for such a species in biological systems is lacking at the present time [13]. Ross and Rosenzweig review the current state of knowledge on the role of copper in particulate methane monooxygenases and compare the insights obtained to date to those from the better understood diiron-containing soluble methane monooxygenases [14]. Finally, Kim and coauthors assess the ability of quantum mechanical theory to predict kinetic isotope effects (KIEs) associated with proposed $\left[\mathrm{Cu}_{2}(\mu-\mathrm{O})_{2}\right],\left[\mathrm{Fe}_{2}(\mu-\mathrm{O})_{2}\right]$, and $\mathrm{Fe}(\mathrm{IV})=\mathrm{O}$ oxidants employed for biological $\mathrm{C}-\mathrm{H}$ activation as a tool to connect theory and experiment [15].

The following section focuses on nonheme iron enzymes. Kal and Que review the status of iron enzymes having active sites with a 2-His-1-carboxylate facial triad [16], a recurring motif first recognized 20 years ago [17]. Since that time, the number of enzymes using this motif has multiplied and the scope of transformations catalyzed has dramatically increased. In many cases, a high-valent iron-oxo oxidant must be formed during the catalytic cycle to carry out the desired oxidative transformation. In the following paper by Proshlyakov, McCracken, and Hausinger, one enzyme in this superfamily, namely, TauD or taurine: $\alpha$-ketoglutarate dioxygenase [18], is selected to illustrate what insights into the iron active site can be obtained from the application of various spectroscopic methods to complement what has been learned from X-ray crystallography. Then, Peck and van der Donk discuss nonheme iron enzymes that carry out four-electron oxidations of substrates [19], while Liu and co-authors center on dioxygenases involved in the biodegradation of aromatic molecules [20]. A common feature that emerges from mechanistic investigations of many of these enzymes is the important role played by an iron(III)-superoxo moiety to get the reaction going. Thus, much has been learned about nonheme iron enzymes since the pioneering work of Osamu Hayaishi on catechol 1,2-dioxygenase 60 years ago.
This special issue concludes with two articles. Fiedler and Fischer cover enzymes that activate dioxygen with active site metal centers other than $\mathrm{Fe}$ or $\mathrm{Cu}$, namely, $\mathrm{Mn}$, $\mathrm{Co}$, and Ni and corresponding model systems [21]. Costas and co-authors review progress in the area of bio-inspired iron-catalyzed oxidations of alkanes and alkenes, from the early attempts to reproduce the basic reactivity of nonheme iron oxygenases to the development of effective iron catalysts for stereoselective oxidation [22].

In closing, I thank all the contributors to this special issue for sharing their insights into this fascinating area of inquiry as well as the reviewers for their efforts in helping to improve the quality of the manuscripts.

\section{Lawrence Que \\ JBIC Chief Editor}

\section{References}

1. Hayaishi $\mathrm{O}$ (2005) Biochem Biophys Res Commun 338:2-5

2. Waterman MR (2005) Biochem Biophys Res Commun 338:7-11

3. Mason HS, Fowlks WL, Peterson E (1955) J Am Chem Soc 77:2914-2915

4. Hayaishi O, Katagiri M, Rothberg S (1955) J Am Chem Soc 77:5450-5451

5. Raven E (2017). doi:10.1007/s00775-016-1412-5

6. Hayaishi O, Rothberg S, Mehler AH, Saito Y (1957) J Biol Chem 229:889-896

7. Fujisawa K (2017). doi:10.1007/s00775-016-1432-1

8. Groves JT, Van Der Puy M (1976) J Am Chem Soc 98:5290-5297

9. Huang X, Groves JT (2017). doi:10.1007/s00775-016-1414-3

10. Yosca TH, Ledray AP, Ngo J, Green MT (2017). doi:10.1007/ s00775-016-1430-3

11. Wise CE, Grant JL, Amaya JA, Ratigan SC, Hsieh CH, Manley OM, Makris TM (2017). doi:10.1007/s00775-016-1425-0

12. Quist DA, Diaz DE, Liu JJ, Karlin KD (2017). doi:10.1007/ s00775-016-1415-2

13. Keown W, Gary JB, Stack TDP (2017). doi:10.1007/ s00775-016-1420-5

14. Ross MO, Rosenzweig AC (2017). doi:10.1007/ s00775-016-1419-y

15. Kim Y, Binh KM, Park S (2017). doi:10.1007/ s00775-017-1441-8

16. Kal S, Que L Jr (2017). doi:10.1007/s00775-016-1431-2

17. Hegg EL, Que L Jr (1997) Eur J Biochem 250:625-629

18. Proshlyakov D, McCracken J, Hausinger RJ (2017). doi:10.1007/ s00775-016-1406-3

19. Peck SC, van der Donk WA (2017). doi:10.1007/ s00775-016-1399-y

20. Wang Y, Li J, Liu A (2017). doi:10.1007/s00775-017-1436-5

21. Fiedler AT, Fischer AA (2017). doi:10.1007/s00775-016-1402-7

22. Olivo G, Cussó O, Borrell M, Costas M (2017). doi:10.1007/ s00775-016-1434-z 